\title{
ELECTRICAL TECHNIQUE FOR MONITORING WETTING PATTERN UNDER TRICKLE SOURCE
}

\author{
S. M. Ismail ${ }^{1}$, T. K. Zin El-Abedin ${ }^{1}$ and A. Abd El-Al ${ }^{2}$
}

\section{A BSTRACT}

Knowledge of the wetted pattern dimensions is important in designing and managing efficient drip irrigation systems. Distance between emitters, root zone depth and emitter flow rates must be matched to the soil's wetting characteristics and the amount and timing of water to be supplied to meet the crop needs. To estimate the wetted pattern dimensions correctly during laboratory experiments in soil section, the wetting front progress should be allowed to move freely into the soil profile in all directions. The developed technique depending on number of electric circuits distributed on steel axes (electrical measurement axes) inside a wooden rectangular soil box was used to determine the wetting front movement. This technique of determining wetted pattern dimension, avoids the side effects of the Plexiglass wall, in conventional technique, on the soil moisture movement. As a result, the obtained wetted pattern agrees closely to that described by Zur (1999) and Ismail et. al (2006).

Keywords: Drip irrigation systems, Wetted pattern.

\section{INTRODUCTION}

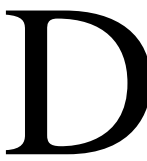
rip or trickle irrigation, by which water is applied slowly through small emitter openings from plastic tubing. Drip tubing and emitters may be laid on the soil surface, buried, or suspended from trellises (Allen, et al. 1999). Through drip irrigation, water is limited to a supply zone around the roots of an individual plant and not wasted on unused soil (Levin, et al. 1979). Such an efficient technique is obviously desirable in areas with restricted availability of irrigation water. The method involves wetting the soil from either a buried (subsurface) or surface point source (Bresler, 1975). Therefore, Drip irrigation is the most suitable method for sandy soil to save water because it is far more controlled. Water is slowly provided to a very specific area, close to the roots of the plant, by a network of drip emitters.

1 Prof. Dr. of irrigation systems, Agric. Eng., Fac. of Ag., EL-Shatby, Alex. Univ.,Egypt.

2 Lecturer., Agric. Eng., Fac. of Ag., EL-Shatby, Alex. Univ.,Egypt. 
Zazueta, et al. (1996) reported that dimensions of the wetted pattern and the soil-water content of the wetted pattern affect yield and quality of the crop. Zur (1999) stated that depth dimension of wetted pattern should coincide with the depth of the root system while width dimension of wetted pattern should be related to the spacing between emitters and lines. Zur (1999) pointed out that the geometry of the wetted pattern under drip irrigation takes a spherical or ellipsoidal-like shape when water is applied from a point source or a cylindrical-like shape when water is applied from a line source. The boundaries of the wetted pattern are reasonably well defined and are surrounded by drier soil. The dimensions of the wetted pattern as shown in Fig. (1 ), D is the maximal width occurring at a depth $\mathrm{h}$ below the soil surface, $\mathrm{Z}$ is the vertical extend of this volume, and $\mathrm{d}$ is diameter of the saturated zone of water pond .

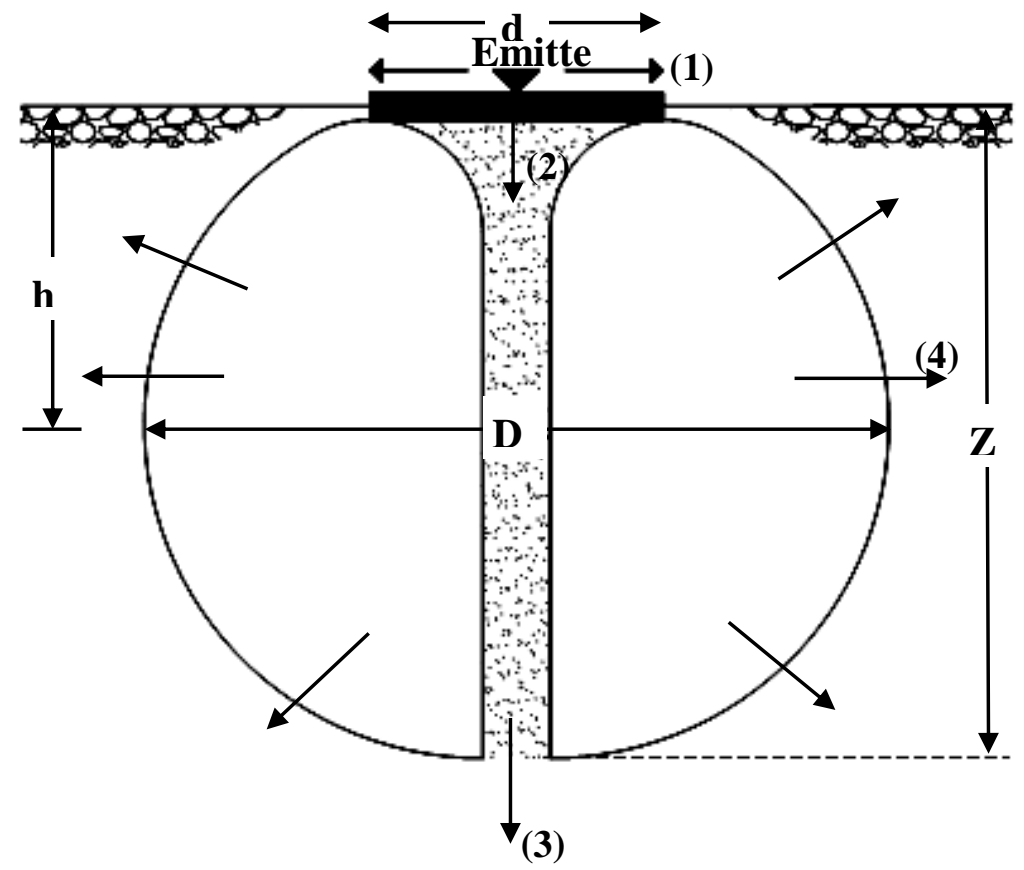

Figure (1) The dimensions of the wetted pattern (Zur (1999)) and driving force to water movement through wetted pattern (Rosenfeld (2000))

Rosenfeld (2000) explained that the four ways of water movement under a drip irrigation point source are volume and time dependent (as shown in Fig. (1)): 
1- Ponding: as the instant emitted flow increases over the infiltration rate capacity of the soil, a bigger pond develops below the source.

2- Saturated core: configured if water drips during a sufficiently long period of time.

3- Vertical percolation: quick movement by gravity action.

4- Diffusion: by means of capillarity, water moves in all directions in relation with hydraulic conductivity of soil.

To monitor the wetted pattern dimensions in laboratory, the dimensions were measured in soil sections similar to the soil in the field. Ismail (1993) and Ismail et. al (2014) suggested a rectangular laboratory model which was constructed from plexiglass so that the two-dimensional movement of the wetting front and the volume of water drawn from the buried water well could be observed. The 90x60x10 $\mathrm{cm}$ model was assembled with the water well at its center. The model design assumed that the soil-wicks in the pipe are sufficiently close together so that the flow away from the pipe is uniform along the length of the pipe. With this assumption, the model provides a two-dimensional pattern of the movement of the wetting front. The wetting front was measured in the horizontal and vertical directions from the centerline of the pipe as a function of the time. The pattern of the wetting front was drawn on a transparent plastic sheet for each time increment.

Zin El-Abedin et. al (1996), Zin El-Abedin (2006) used the same model with the the dripper line. The traditional procedures were conducted on a wooden rectangular soil box with Plexiglass transparent side. Where the dripper line was $5 \mathrm{~cm}$ apart from Plexiglas side which allowed to observe the movement of the wetting front. The wetted pattern was projected on the transparent paper sheet fixed on Plexiglas side of the soil box.

This technique, although widely used, was not completely accurate because of the side effects of the Plexiglass on the moisture movement in the all direction.

Therefore, to estimate wetted pattern accurately, wetting front should be moved freely into the soil profile in all directions. So using an electrical circuit would be helpful to monitor the wetting front progress into the soil to determine the wetted pattern dimension ( Abd El-Al (2007), Ismail et. al (2006), Ismail et. al (2008)). 


\section{MATERIALS AND METHODS}

El-Bustan soil region was selected to represent the typical soil type in Egypt new lands. The soil was brought from the top layer of $40 \mathrm{~cm}$ depth using a shovel and placed in heavy - duty ( $1.6 \mathrm{~mm}$ thick ) polyethylene bags. The bags were transported to the irrigation laboratory of the Agricultural Engineering Department, Alexandria University.

Soil samples were taken for soil analysis to determine field bulk density and particle size distribution. The $\mathrm{pH}$, basic infiltration rate ( I ), field capacity ( FC ), permanent wilting point ( PWP ), saturated hydraulic conductivity ( Ks ) and electrical conductivity ( Ec ) were also measured. These results of the soil analysis are presented in Table ( 1 ).

Table ( 1 ) some soil physical characteristics

\begin{tabular}{|c|c|c|c|c|c|c|c|c|c|c|c|}
\hline \multirow{2}{*}{$\begin{array}{c}\text { Depth } \\
(\text { cm) }\end{array}$} & \multicolumn{3}{|c|}{$\begin{array}{l}\text { Practical size } \\
\text { distribution \% } \\
\end{array}$} & \multirow[t]{2}{*}{$\begin{array}{c}\text { Soil } \\
\text { Texture }\end{array}$} & \multirow{2}{*}{$\begin{array}{l}\mathbf{F C} \\
\%\end{array}$} & \multirow{2}{*}{$\underset{\%}{\mathbf{P W P}}$} & \multirow{2}{*}{$\begin{array}{c}\text { BD } \\
\mathrm{g} / \mathrm{cm}^{3}\end{array}$} & \multirow{2}{*}{$\underset{\mathbf{m} / \mathbf{d}}{\mathbf{I}}$} & \multirow{2}{*}{$\begin{array}{c}\mathbf{E C} \\
\mathbf{d s} / \mathrm{m}\end{array}$} & \multirow{2}{*}{$\underset{\mathbf{m} / \mathbf{d}}{\mathbf{K s}}$} & \multirow[t]{2}{*}{$\mathbf{p H}$} \\
\hline & Sand & Silt & Clay & & & & & & & & \\
\hline $0-40$ & 98.75 & 0.8 & 0.45 & sandy & 10.9 & 5.2 & 1.61 & 9.12 & 1.3 & 3.16 & 8.2 \\
\hline
\end{tabular}

\section{Experimental apparatus}

Experiments were conducted on a wooden rectangular soil box. The soil box was designed to simulate a soil section in the field. It was made from $16 \mathrm{~mm}$ thick wood with a dimensions of $55 \times 50 \times 55 \mathrm{~cm}$ and painted with water prove paint to avoid water absorption. The soil box was attached to the dripper line, one end was connected to pressure gauge, control valve, small pump and $0.4 \mathrm{~m}^{3}$ water tank and the other end was plugged.

The dripper line (GR $20 \mathrm{~mm}$ diameter ) was laid on the surface in the middle of the soil box with one emitter in the middle of the line. Three different operating pressures were used to determine the wetting front movement (1, 1.5, 2 bar $)$ at four different irrigation times $(15,30,45$ and $60 \mathrm{~min}$. ).

\section{Electric wetted bulb spread recording}

The suggested electric circuit consisted of two poles ( negative and positive ), led and direct current converter ( from AC to DC 9 volt ), as shown in Fig. (2).

The two poles hold a sample of air dried soil, therefore the circuit does not sense any signal even if the power was connected as shown in Fig. (2a). In order for the electric circuit to respond, the soil between the two poles should be completely wetted. Then, simultaneously, the electric circuit will be closed and the led will be on to indicate that the wetting 
front has been reached to this point as shown in Fig. (2b), this idea is used in the pluviometer instrument.

Based on the previous procedure used to predict the wetting front progress at one point, a number of these circuits were made in threedimensions to determine the wetted bulb in the whole soil profile.

These electric circuits were distributed in each dimension on a holding steel axis which acts as the negative pole. The positive pole was a number of steel rings which were insulated by plastic nuts as shown in Fig (3). Each steel ring with holding axis composed an electrical circuit. The steel ring and the holding axis were connected to a led indicator and DC power.

Each axis was holding 10 electrical circuits. The spacing between any of them is $4 \mathrm{~cm}$ apart. Every direction was identified by led board having a number of led indicators equal to the number of the steel rings ( the electric circuit units ) which arranged in the same way as shown in Fig. (4). Any of these axes was called " a measurement axis ". Seven measurement axes were installed to record the wetted bulb spread in the soil profile.

The soil profile was divided into four horizontal planes. The spacing between planes was $10 \mathrm{~cm}$. The first plane was the soil surface, where the wetting front progress was determined manually, by observation, using a measuring tape.

Each remainder plane was represented by two measurement axes. These axes were identified by $\mathrm{X}$ and $\mathrm{Y}$ dimensions. They were perpendicular and divided each other into two parts (right and left). Steel ring group in each part was facing the wetting front progress (arranged from inside to outside).

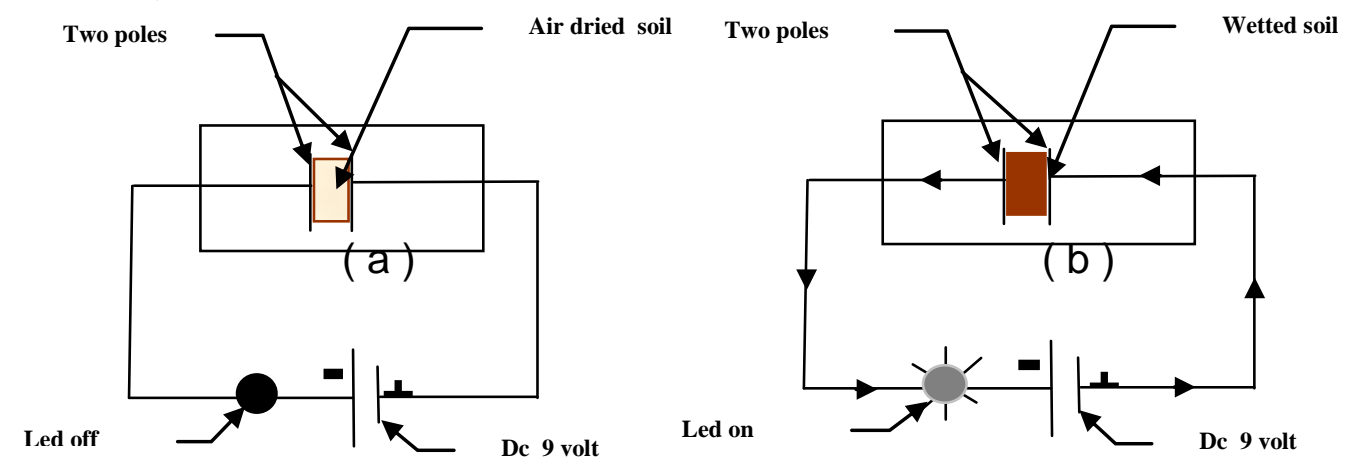

Figure (2) The electric circuit a) opened when soil dry

b ) closed when soil wetted 


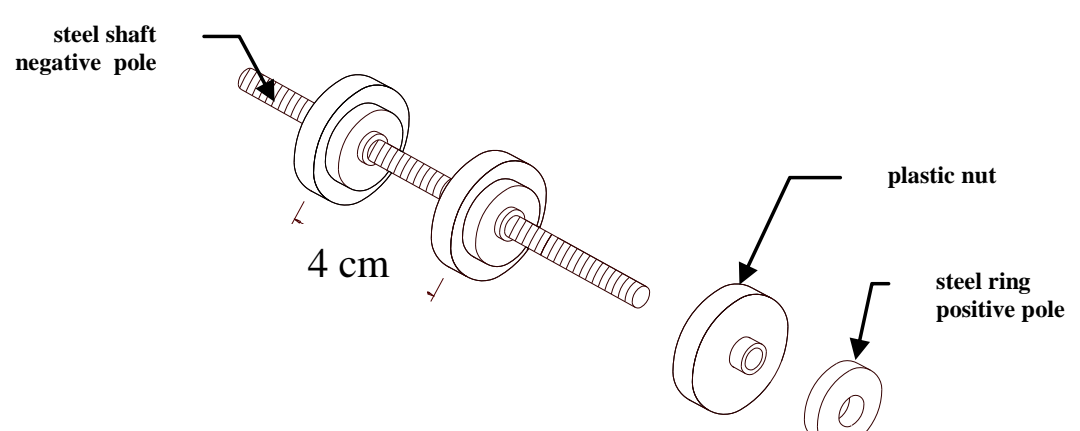

Figure (3) The measurement axis
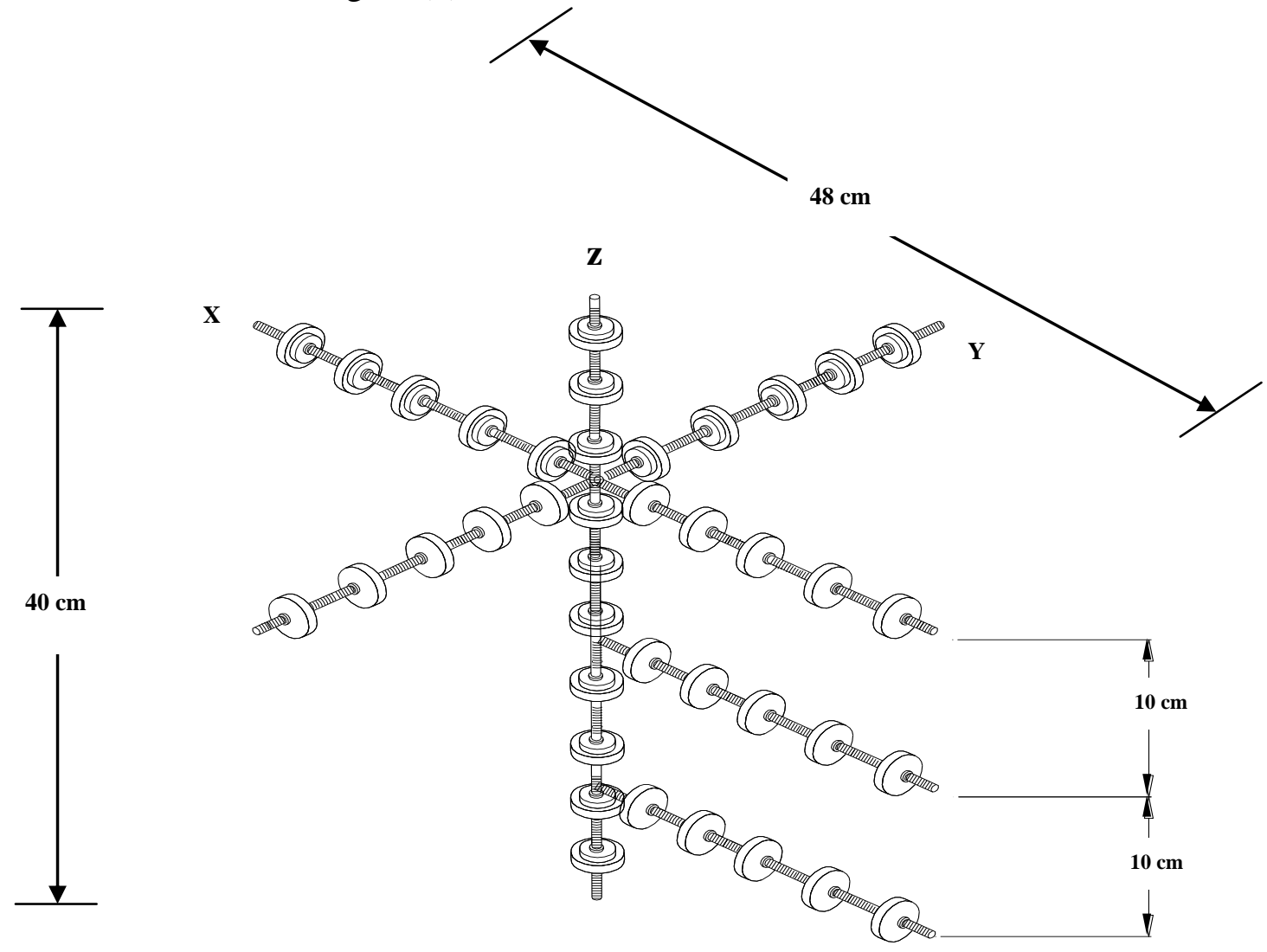

Figure ( 4 ) The measurement axes in three directions (Y, X , Z )

The last axis was in $\mathrm{Z}$ dimension. It was placed in the center of the soil profile at the $\mathrm{X}, \mathrm{Y}$ axes intersection directly under the emitter. The $\mathrm{Z}$ axis holds 10 steel ring facing the wetting front progress (arranged top down). Seven boards were manufactured and assembled; each board was connected to a measurement axis. The $\mathrm{X}, \mathrm{Y}$ axes boards have two 
different LED colors because the intersection point divided the horizontal plan ( X, Y plane ) into right group with green LEDS and left group with yellow LEDS. While the $\mathrm{Z}$ axis board have one led color (green). The boards were fixed and organized in a simple order to facilitate the data collection process.

Figure ( $5 \mathrm{a}, \mathrm{b}$ and $\mathrm{c}$ ) shows the wetted bulb produced in the soil box under three different pressures $\left(\mathrm{P}_{1}, \mathrm{P}_{2}\right.$ and $\left.\mathrm{P}_{3}\right)$.

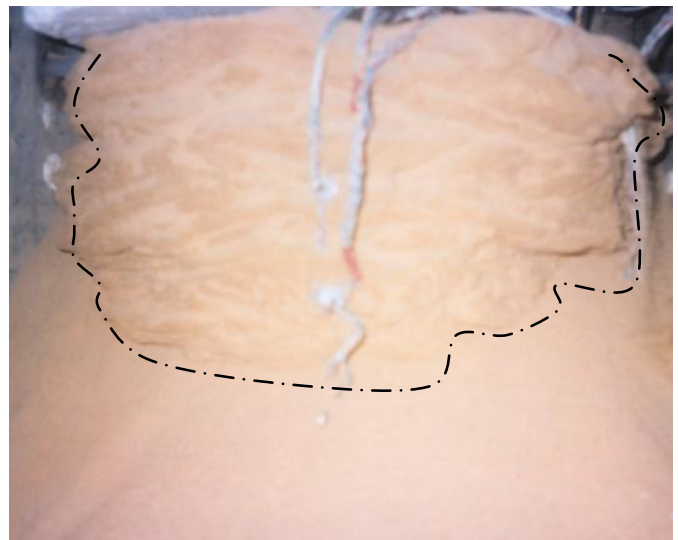

( a )

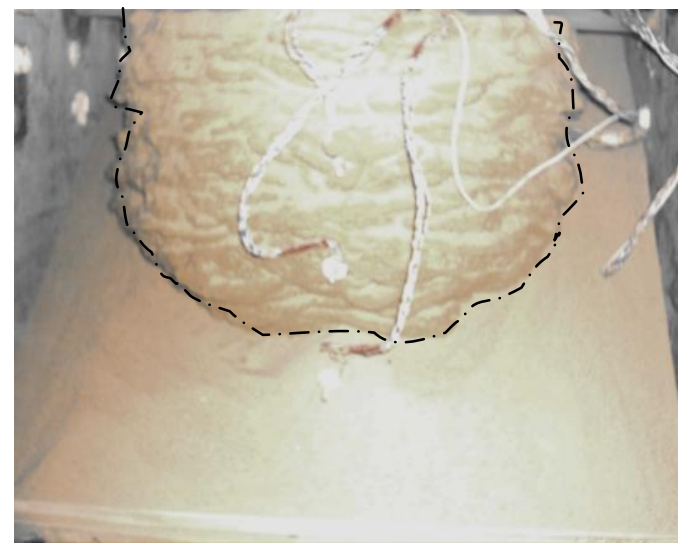

( b )

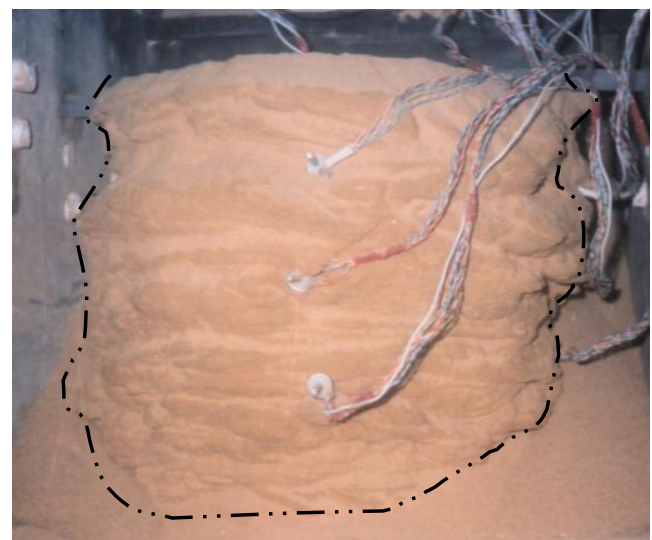

( c )

Figure (5) The wetted bulb produced in the soil box under different three operating pressures
a ) 1 bar operating pressure
b ) 1.5 bar operating pressure
c ) 2 bar operating pressure 


\section{RESULTS AND DISCUSSION}

The wetted bulb was determined according to the data which were collected from the reading of the axes boards $\mathrm{X}, \mathrm{Y}$ and $\mathrm{Z}$ under three different operating pressures $\left(\mathrm{P}_{1}, \mathrm{P}_{2}\right.$ and $\left.\mathrm{P}_{3}\right)$.

The data of wetted bulb in direction $(\mathrm{X}, \mathrm{Y}, \mathrm{Z})$ were plotted by computer program (Golden Surfer version 8) which predicted missing values in data and plotted the wetted bulb. The water front distribution was plotted in two dimensions diagram $(\mathrm{X}, \mathrm{Z})$ or $(\mathrm{Y}, \mathrm{Z})$ between the depth $(\mathrm{cm})$ and the distance of wetted front progress from the water emission as a function of time ( contour line 15, 30, 45, $60 \mathrm{~min}$ ) as shown in Fig. ( $6 \mathrm{a}, \mathrm{b}$ and c ).

Figure (6) showed that the water front distribution in 2D diagram ( $X, Z$ ) was approximately equal to the water front distribution in 2D diagram ( $\mathrm{Y}, \mathrm{Z}$ ), however, the water front distribution was similar around the $\mathrm{Z}$ axis. Figure (6) also demonstrates that the maximum diameter wetted by dripper occurred near the soil surface, $10 \mathrm{~cm}$ deep.

The electric circuit technique presented in this research (Fig. 6) showed that the wetted pattern takes the spherical shape under low pressure, while it takes the ellipsoidal shape under high pressure.

Also, the average wetted bulb dimensions were determined (" Z ", "d" and "D") at different times (15, 30, 45, $60 \mathrm{~min})$ and diameter ratio between the surface diameter and maximal diameter under different operating pressures (1, 1.5 and 2 bar) as shown in Fig. ( 6 ) and presented in Table ( 2 ). It can be shown that as run time increased, the diameter ratio (d/D) decreased. Similarly, as the operating pressure increased, the diameter ratio decreased. However, the depth ratio $(Z / D)$ decreased, as the run time increased. It also can be seen that the depth ratio increased as operating pressure increased. These results demonstrate that excessive applications could easily extend the vertical movement below the root zone. Light frequent applications tend to minimize losses from deep percolation.

\section{CONCLUSION}

The electric circuit technique developed in this study can be used to monitor wetted bulb dimensions under trickle source without the side effect of plexiglass wall on soil moisture movement. 
$(\mathrm{Y}, \mathrm{Z})$
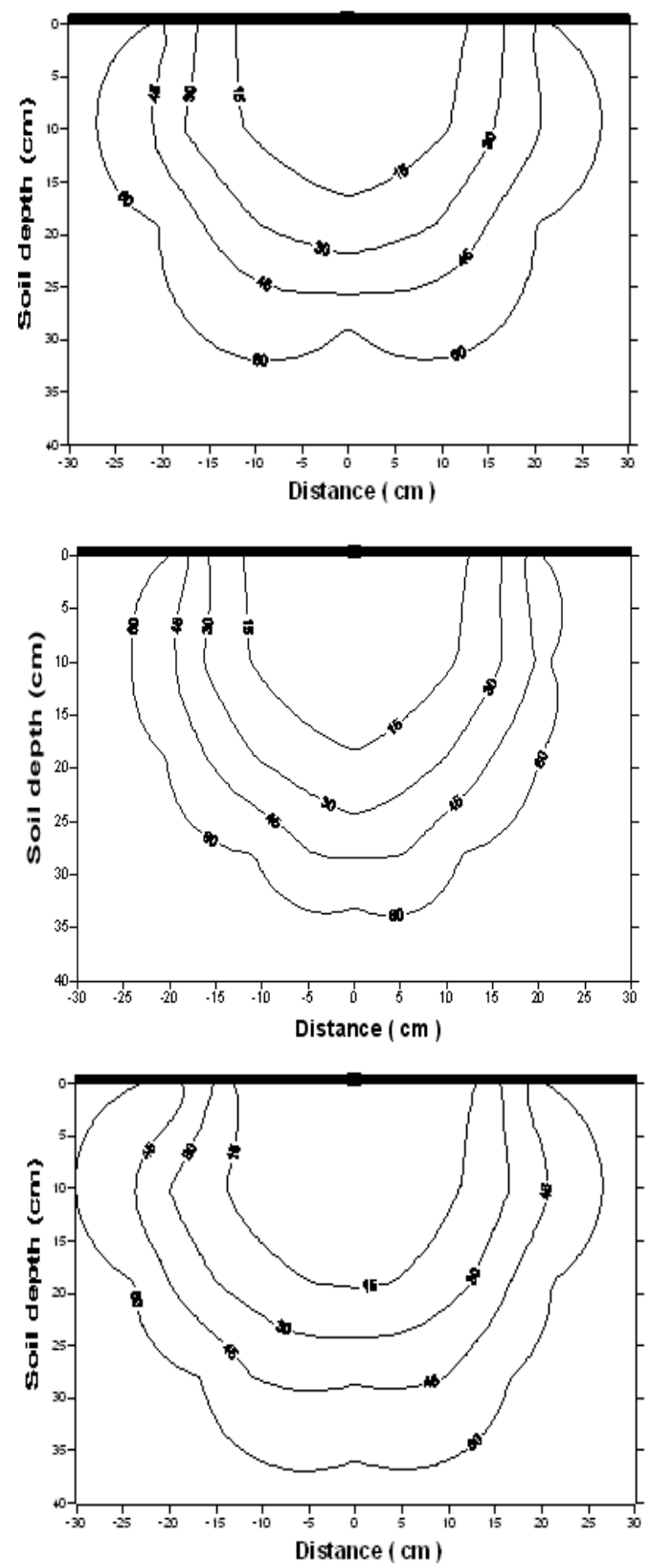

$(\mathrm{X}, \mathrm{Z})$

a) $\mathrm{P}$

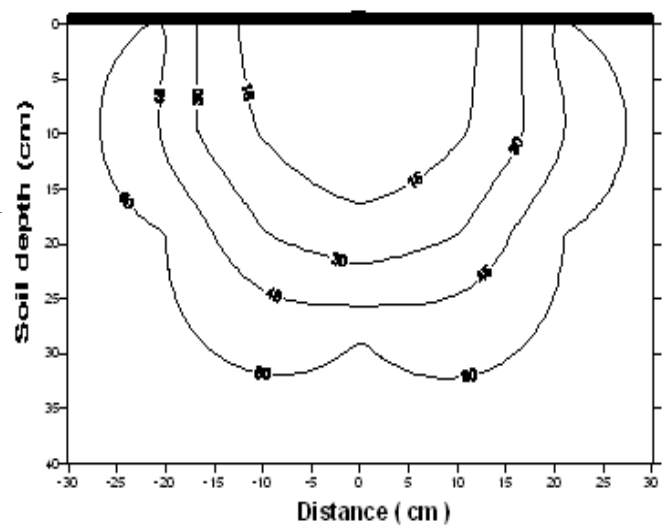

b ) $\mathrm{P}_{2}$
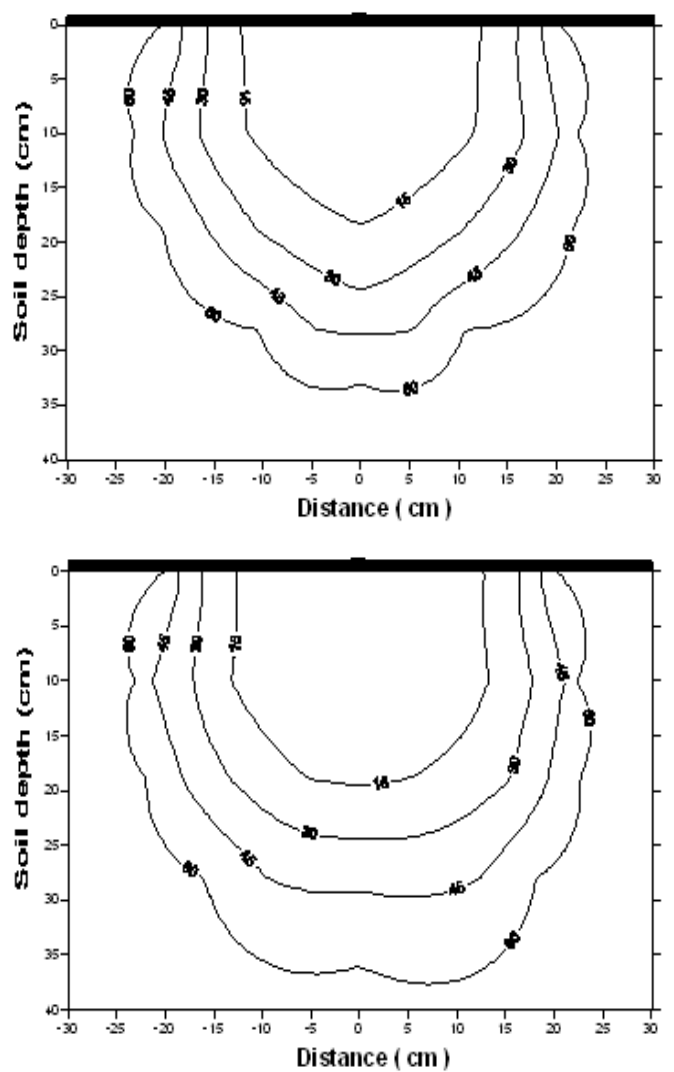

Figure ( 6 ) The water front distribution as a function of time ( $\min$ ) under different operating pressures in $2 \mathrm{D}$ diagram $(\mathrm{Y}, \mathrm{Z})$ and $(\mathrm{X}, \mathrm{Z})$. 
Table ( 2 ) The average wetted bulb dimensions at different time(min) under different operating pressures

\begin{tabular}{|c|c|c|c|c|c|c|c|c|c|c|c|c|}
\hline $\begin{array}{c}\text { Application time } \\
\text { "min" }\end{array}$ & \multicolumn{3}{|c|}{15} & \multicolumn{3}{c|}{30} & \multicolumn{3}{c|}{45} & \multicolumn{3}{c|}{60} \\
\hline $\begin{array}{c}\text { operating pressure } \\
\text { (bar) }\end{array}$ & 1 & 1.5 & 2 & 1 & 1.5 & 2 & 1 & 1.5 & 2 & 1 & 1.5 & 2 \\
\hline $\begin{array}{c}\text { Emitter flow rate } \\
\text { (l/hr) }\end{array}$ & 5.17 & 6.12 & 7.42 & 5.17 & 6.12 & 7.42 & 5.17 & 6.12 & 7.42 & 5.17 & 6.12 & 7.42 \\
\hline $\begin{array}{c}\text { The vertical depth } \\
\text { Z (cm) }\end{array}$ & 16.3 & 18.3 & 19.6 & 21.8 & 24.3 & 25.0 & 25.7 & 28.5 & 29.7 & 28.9 & 33.2 & 36.2 \\
\hline $\begin{array}{c}\text { The surface } \\
\text { diameter d (cm) }\end{array}$ & 24.6 & 24.5 & 25.5 & 33.1 & 31.6 & 32.6 & 40.2 & 36.9 & r. . & 44.1 & 41.7 & 41.5 \\
\hline $\begin{array}{c}\text { The maximal } \\
\text { diameter D(cm) }\end{array}$ & 24.6 & 24.5 & 25.5 & 33.9 & 33.2 & 35.4 & 42.1 & 40.7 & $\varepsilon r . \varepsilon$ & 55.7 & 51.0 & 53.1 \\
\hline $\begin{array}{c}\text { Diameter ratio } \\
\text { (d/D) }\end{array}$ & 1.00 & 1.00 & 1.00 & 0.98 & 0.96 & 0.93 & 0.96 & 0.91 & 0.88 & 0.80 & 0.82 & 0.79 \\
\hline Depth ratio (Z/D) & 0.67 & 0.75 & 0.77 & 0.65 & 0.74 & 0.71 & 0.62 & 0.71 & 0.71 & 0.52 & 0.66 & 0.69 \\
\hline
\end{tabular}

\section{REFERENCES}

Abd El-Al A. ( 2007 ). Comparison of Some Different Methods of Estimating Drip Irrigation Wetted Pattern . M.Sc. thesis, Agric. Eng. Dep., Faculty of Agric., EL-Shatby, Alexandria University.

Allen R. G., J. Amsler and V. Bagarello, 1999. CIGR Handbook of Agricultural Engineering Volume I. The American Society of Agricultural Engineers. LCCN 98-93767. ISBN 1-892769-01-8.

Bresler, E., 1975. Two-dimensional transport of solute during nonsteady infiltration from a trickle source. Soil Sci. Soc. Am. Proc. 39:604613.

Ismail, S.M. 1993. Soil- wick self- regulating subsurface irrigation. Misr J. Ag. Eng., Vol. 10 ( 1 ) : 44- 52.

Ismail, S.M., T.K. Zin El-abedin, A. Wassif, and M. N. El-Nesr 2006 Drip irrigation systems in sandy soil using physical and hydraulic barriers. Misr J. Ag. Eng. 23(4):1021-1034.

Ismail, S.M., T.K. Zin El-abedin, A. Wassif, and M. N. El-Nesr 2006. Wetting pattern simulation of surface and subsurface drip irrigation 
systems. II- Model validation and analysis. Misr J. Ag. Eng. 23(4):1035-1057.

Ismail, S.M., T.K. Zin El-abedin, A. Wassif, and M. N. El-Nesr 2006. Wetting pattern simulation of surface and subsurface drip irrigation systems. I- Model development. Misr J. Ag. Eng. 23(3):722-746.

Ismail, S.M., T.K. Zin El-abedin and A. Abdel-Ala 2008. A simple equation to estimate the recommended emitters spacing to suit the root depth and soil texture. J. Saudi Soc. for Agric. Sci. Vol. 7, No 2; 2008 (43-57).

Ismail, S.M., T.K. Zin El-abedin, A. Omara, and E. Abdel-Tawab, 2014. Modeling the Soil Wetting Pattern under Pulse and Continuous Drip Irrigation. American-Eurasian J. Agric. \& Environ. Sci., 14(9): 913-922.

Levin, I., van Royen, P.C., van Rooyen, F.C., 1979. The effect of discharge rate and intermittent water application by point-source irrigation on the soil moisture distribution pattern. Soil Sci. Sot. Am. J. 43, 8-16.

Rosenfeld B., 2000. Pulsed Ultra-low Volume Irrigation. SEIS Application Notes. 22 may 2000.26 oct 2002. $<$ http://www.microirrigationforum.com/new/powerpoint/ English\%20version/ index.htm>.

Zazueta F.S., G.A. dark, A.G. Smajstria and M. Carrillo, 1996. a Simple Equation to Estimate Soil-Water Movement from a Drip Irrigation Source. Florida Agric. Exp. Stn. Journal Series No. NR-00996.

Zin El-Abedin, T. K.; G. A. Sharaf, and S. M. Ismail. 1996. Subsurface drip line irrigation system. II. Modeling the soil-moisture distribution. Misr J. Ag. Eng., Vol.13(3) : 589-604

Zin El-Abedin. 2006. Improving moisture distribution pattern of subsurface drip irrigation in sand soil by using synthetic soil conditioner. Misr J. Ag. Eng., Vol.23 (2) : 374-398

Zur B., 1999. Wetted Soil Volume as a Design Objective in Trickle Irrigation. Irrig. Sci., Vol. 22, pp.19-30. 


\section{الملخص العربى \\ تقنية كهربائية لمراقبة شكل الابتلال تحت الري بالتنقيط المربي

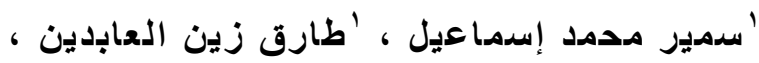

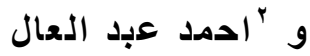

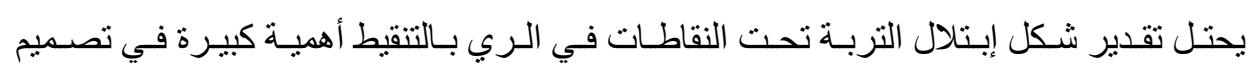

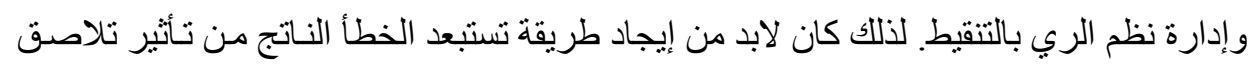

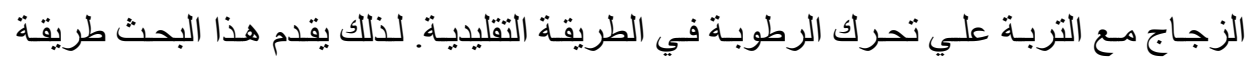

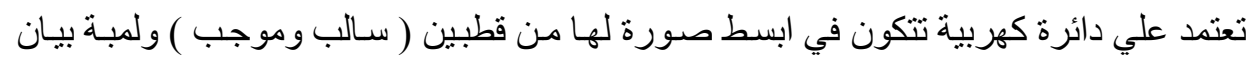

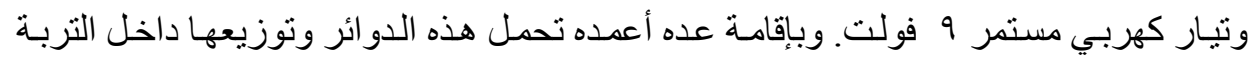

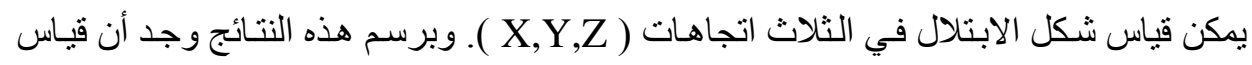

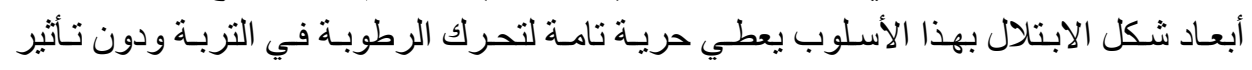
لتلاصف اللوح الزجاجي مع التربة.

ا أستاذ هندسة نظم الري، قسم الهندسة الزراعية، كلية الزراعة، الثاطبى، جامعة الإسكندرية. r مدرس هندة نظم الري، قسم الهندسة الزراعية، كلية الزراعة، الثناطبى، جامعة الإسكندرية. 